\title{
Comparative Study of SMART and FMCDM Methods in Smartphone Selection Decision Support System
}

\author{
Novhirtamely Kahar, Riki \\ Informatics Engineering, Computer Science Faculty, Universitas Nurdin Hamzah, Jambi, Indonesia \\ Email: novmely@ymail.com, riki68005@gmail.com
}

Received: 12 December 2020; Accepted: 28 February 2021; Published: 08 August 2021

\begin{abstract}
Smartphones are one of the communication technology tools currently used by both children and the elderly, so that interest in shopping for smartphones in Indonesia is increasing. The variety of smartphone brands makes buyers confused about which smartphone to buy. This research can help buyers to choose a smartphone to buy and help sellers provide recommendations. This study applies the Simple Multi Attribute Rating Technique (SMART) and Fuzzy Multi Criteria Decision Making (FMCDM) methods for the decision making process for smartphone selection. The purpose of this study is to apply and analyze the comparison of the SMART method and the FMCDM method in the Smartphone Selection Decision Support System. The study compared: the differences and similarities between the two methods, the results of the selection process for the two methods, and calculating the value of the sensitivity analysis of the selection results so that the best method could be determined. The criteria used: price, screen size, battery capacity, operating system, RAM, camera, and smartphone brand. The comparison results show that there are differences between the standard for determining the results, while the similarities in the calculation results, the smartphone recommended to buy is the same, namely the Asus Zenfone 2 Laser ZE500KG (16 GB) smartphone. Measurement of the accuracy of the results of the two methods uses sensitivity analysis values. It can be concluded that the better method is the FMCDM method because it has a smaller average sensitivity value than the SMART method, namely $0.2795<0.3906$.
\end{abstract}

Index Terms: Decision Support System (DSS), Smartphone, SMART, FMCDM, Sensitivity Analysis.

\section{Introduction}

Decision support systems couple the intellectual resources of individuals with the capabilities of the computer to improve the quality of decisions. It is a computer-based support system or management decision makers who deal with semistructured problems[1]. Decision support systems can also be interpreted as a computer-based system that can manage data into information for decision-making purposes in specific decision-oriented issues and is oriented towards future planning and is used at unusual times. Decision support systems are used with the aim of increasing effectiveness but not for efficiency in making decisions made by decision makers. Some of the methods commonly used to assist the Decision Support System process include the Profile Matching method, Simple Multi Attribute Rating Technique (SMART) and methods related to Artificial Intelligence systems such as Expert Systems, Artificial Neural Networks, and fuzzy logic. One of the Fuzzy logic methods is the Fuzzy Multi Criteria Decision Making (FMCDM) method. This research will apply the use of the SMART method and the FMCDM method in making smartphone selection decisions on Maju Jaya Cell Store.

The current era of the industrial revolution 4.0, the industry is starting to touch the virtual world, in the form of human, machine and data connectivity, everything is everywhere. This term is known as the Internet of Things (IoT). The concept of the "Internet of Things" originated in 1999 from work examining how to link objects to the Internet through an RFID (Radio Frequency Identification) tag [2-3]. Data or big data can be transferred via IoT objects that are connected to the network without any interaction between humans and humans or between humans and computers. One of the implementation of IoT is smart mobile device or smartphone, can make remote software updating possible [4-5]. For example, a smart city that can be controlled via a smartphone with the help of an internet connection. Smartphones are mobile phones that have the advantage of smarter software and hardware specifications, smarter functions and smarter features than previous regular versions of cell phones [6-7]. In addition to helping human activities, through smartphones, consumers can share experiences and important moments in their lives on Instagram, Facebook, and other social media. This has led to an increase of 21 percent (1.2-fold) in smartphone shopping interest in Indonesia in the last 2 years, while for products in the gadget and electronic category it has increased 50 percent (1.5 times) in the last 2 
years [8]. Maju Jaya Cell Store is one of the kiosks that sells cellphones, smartphones, pulses and accessories from these devices. Maju Jaya Cell Store is located at Muara Tembesi. Every day there are sales and purchase transactions at Maju Jaya Cell Store, one of which is the sale and purchase transactions of smartphones [9]. Various types of smartphones are offered with different facilitation and have their respective advantages, sometimes customers experience confusion about which smartphone to buy, so it takes a long time to choose a smartphone. Long service to buyers resulted in other buyers lining up to get service, service to buyers was felt to be less than optimal and buyers became quiet, resulting in reduced shop turnover. Buyers also have to adjust their budget so that buyers are satisfied with the smartphone they purchased so that buyers can return to the store to buy other types of smartphones. To assist customers in choosing a smartphone, an effective and efficient Decision Support System (DSS) or computerized decision support system is needed that can help buyers or customers quickly make decisions about which smartphone to buy.

In addition, in selecting the method that will be applied to build the decision support system, the decision maker, in this case the policy maker is also sometimes confused in choosing the best method to use in this case, because based on several previous studies, various methods have been recommended to be applied. Because it has different performance. To assist in the selection of methods in the decision support system, a comparative study will be carried out on the use of 2 methods in the Decision Support System for smartphone selection with the FMCDM method whose results will be compared with the SMART method based on the results of previous studies [9] using the same parameters or criteria.

The SMART (Simple Multi Attribute Rating Technique) method is a method that can solve multicriteria decisionmaking problems. This method is a decision-making method developed by Edward in 1997 [10]. This multi-criteria decision-making technique is based on the theory that each alternative consists of a number of criteria that have values and each criteria has a weight that describes how important a criteria is compared to other criteria. This weighting is used to assess each alternative in order to obtain the best alternative [11]. Fuzzy Multiple Criteria Decision Making (FMCDM) is a decision-making method to determine the best alternative from a number of alternatives based on certain criteria. Criteria are usually in the form of measures, rules or standards used in decision making. The MCDM process is carried out in 3 stages, namely the preparation of situation components, analysis and synthesis of information. At the stage of compiling the components of the situation an estimate table will be formed which contains the identification of alternatives and specification of objectives, criteria and attributes [12]. In general, both methods are methods that both use several attributes or criteria that have weight values as the basis for decision making.

In previous research, the Decision Support System using the FMCDM method can be implemented well in various cases including selection supplier case, namely A hybrid FMCDM model for selecting a sustainable supplier of forklift filters [13], performance evaluation case, The applying FMCDM method to the performance evaluation scores of industrial design courses [14], the selection ideal teacher case, namely the decision support for the selection of ideal teacher positions [15], and the managerial case, namely Sustainable risk management strategy selection using a fuzzy multi-criteria decision approach [16]. Meanwhile, the application of DSS using the SMART method includes: in the selection students case, namely Decision support system for selecting students to follow biological science olympiad using Simple Multi Attribute Rating Technique (SMART) method [17], in employ performance case, namely Employee performance evaluation Decision Support System with the SMART (Simple Multi-Attribute Rating Technique) method [18], and in the beauty business case, namely Implementation of Simple Multi Attribute Rating Technique method using Decision Support System concept (Case Recommendation Of Salon Place In Pematangsiantar City) [19]. Good implementation of the SMART and FMCDM methods in various cases in the decision support system sometimes makes the decision maker confused in choosing the method to use because all methods are considered good but the level of accuracy cannot be measured. So it is necessary to have preliminary learning regarding the comparison of several methods.

Research that discusses the theme of comparing two or more methods has existed in previous studies, including: comparison of the SMART and MADM SAW methods of determining permanent employees [11], resulted in the conclusion that the results of the SAW method were closer to the specified standard values. Another research study is the sensitivity analysis of the SMART-AHP model with the SMARTER-ROC in the analysis of oil palm productivity policies [20] which resulted in the conclusion that the results of the SMARTER-ROC method were better because they had smaller sensitivity values than the SMART-AHP method. In other, namely comparative study of integrated FMCDM methodology including FAHP, WASPAS-F, EDAS-F and ARAS-F [21] which resulted an important finding of the study is that the ranking results of the proposed methods are consistent with each other. In research Comparison of the ELECTRE, SMART and ARAS Methods in Determining Priority for Post-Natural Disaster RENAKSI Priorities [22] wich resulted The correlation value of the ARAS method is greater than the ELECTRE and SMART methods. From the comparative research of several methods above, it is concluded that both the SMART method and the Fuzzy Logic method are considered the best.

Research on Smartphone Selection Has Been Existing, Including Research Methodology: Prioritization of new smartphones using Topsis And Moora [23], the criteria used are 5 criteria: battery, camera, screen size, cost, and performance. The decision result of the two methods shows the same result, namely the Samsung smartphone, but has not yet explained which method has the best performance value. Another research is the Decision Support System for android smartphone selection using the Smarter and Topsis method [24], the criteria used are 4 criteria: brand, variant, 
price, and specifications. The results of this study are that the value of user satisfaction responses to the results of the combination of the SMARTER and TOPSIS methods is measured using a Likert scale, which is $81 \%$, and it has not concluded which method is the best among these two methods.

Based on the above background, the main purpose of this study is to compare the application of the SMART and FMCDM methods in making decisions about choosing smartphones to be purchased by customers. The comparisons in this study are: 1) the differences and similarities between the two methods; 2) Result of selection decision; 3) Calculating the sensitivity value of the results. The results of the comparison in this study will provide a new theory, namely the best method between the SMART and FMCDM methods. The importance of comparing these two methods is to find out which method has better performance when applied to the case of SPK smartphone selection, and the performance of a method can be determined, one of which is by sensitivity analysis. The method that has the better performance can also be tried to apply to other troubleshooting cases. In addition, this study also aims to try to improve the performance of a method from the results of the comparison so that the method is considered feasible to be applied in solving various decision support problems.

\section{Methodology}

This research focuses on one specific object and is limited to studying it as a problem, meaning that this research only applies to the analyzed cases. The research method can be described using a research framework with the following stages:

1. Problem analysis. Analyze research problems based on previous research and the selection problem of smartphone selection by customers at Maju Jaya Cell Store.

2. Analyze theory. Analyzing decision support systems in determining which smartphones are recommended for purchase by customers.

3. Specify input:

a. Criteria: Price, Screen Size, Battery Capacity, Operating System, RAM, Camera, dan Brand.

b. Subcriteria: Very Good, Good, Enough, Less, dan Very Less.

c. Alternative: specifications of each type of smartphone.

4. Define processes: calculations with SMART and FMCDM.

5. Setting the output: the ranking results of smartphones that will be recommended for purchase; comparison of results; and sensitivity analysis.

6. Designing the DSS for smartphone selection. The design is made in the form of a framework to describe the work process of the SMART and FMCDM methods.

7. Implementing the FMCDM method. The application of the application uses the same data as the data on the DSS for smartphone selection using the SMART method.

8. Comparing the FMCDM method with the SMART method in smartphone selection. The comparison criteria are:
a. The value of each criteria and sub-criteria for each alternative
b. Weight value
c. Normalization of weights
d. Calculation process
e. The calculation results
f. Decision Standards

9. Analyzing the research results, namely the results of the comparison of the performance of the FMCDM and SMART methods with the sensitivity analysis method.

10. Make conclusions. Based on data or information obtained from the performance analysis of the SMART and FMCDM methods.

The use of these two methods will be analyzed the comparison with a sensitivity analysis method to test the validity with regard to the relationship between the score and the criterion where the criterion is a free and direct measure of what the measurement wants to predict.

\section{A. Problem Analysis}

The problem in this research, based on the results of previous studies, is the DSS for selecting smartphones using the SMART method [9]. Furthermore, using the same parameters will be tested using the FMCDM method to compare the results. The current system is: The customer selects several smartphones to be compared according to the desired 
criteria. Furthermore, the sales department helps customers in making decisions about choosing a smartphone to buy. The weakness of the current system, buyers are sometimes still confused in determining which smartphone to buy, because usually the selection is only based on following trends without considering the ability and needs of smartphone use.

The use of the SMART method in the DSS for smartphone selection in a previous research [9], the smartphone selection criteria are still static, where the criteria are only limited to 7 (seven) criteria, so that if there are new criteria they cannot be added. This of course results in the decision to choose a smartphone to be stiff and unable to adjust to the new criteria. In addition, if the criteria value for a smartphone that is entered has a good average value for each criteria, then most likely the result of the smartphone recommendation that should be purchased is a smartphone with these good criteria. This means that without the use of DSS, buyers can immediately determine the choice of smartphone that should be purchased only by calculating the total value of each criteria and selecting the highest value.

According to Yeh and Chang 2009, SMART is one of the most applicable MCDM methods, and since the majority of the panelists are not familiar with the MCDM method, this method is simple. SMART has been successfully applied in MCDM problems, but this approach is ineffective when dealing with the ignorance inherent in linguistic assesment in decision making (Gu et al. 2012; Chen and Hou 2004) [25], so for linguistic assessment, the use of the Fuzzy MCDM method (FMCDM) can be applied because the variables used in FMCDM are linguistic variables. Furthermore, the Fuzzy Multi Criteria Decision Making (FMCDM) method is considered very appropriate for the problem of fuzzy (fuzzy or faint) criteria weights [26], for example, the variable price of Rp. 1.000.000,- can be said to be cheap, medium or expensive because human logic in looking at a phenomenon does not only consist of two values, one or zero, but is a multi-value logic gradually from zero to one (gradual) [27]. This Method has been widely adopted to model uncertainties in human decision-making. It also meritoriously resolves uncertainties in collecting data for MCDM. Several researchers have identified that the subjective vagueness of expert judgment can be dispensed by integrating the fuzzy set theory [28-32] with MCDM.

Based on the problem analysis and research objectives, the problem formulation in this study is how to apply the SMART and FMCDM methods to the decision support system for smartphone selection at Maju Jaya Cell Store to make it easier for customers to choose the smartphone to buy based on the criteria set by the seller and the criteria used. different from the previous research criteria which will then be compared the results to draw a conclusion which is the best method between the two methods.

\section{B. Theory Analysis}

In the theoretical analysis, the theories that underlie and relate to the research will be explained, which consists of the completion step using the SMART method, the FMCDM method and the sensitivity analysis to compare the results of the two methods. The theoretical basis is taken from various sources, especially from electronic media, namely electronic books, national and international journals.

\section{SMART Method}

Here is the workflow of the SMART method [9]:

1) Determining alternatives, criteria and sub-criteria.

2) Give weight to each criteria. Granting weights with a scale of 0-100 values based on the priorities that have been inputted.

3) Calculating the normalized criteria weights. The weight obtained will be normalized using equation (1) where the weight of each criteria obtained will be divided by the result of the sum of each criteria weight.

$$
\text { Normalization }=\frac{w_{j}}{\sum w_{j}}
$$

Information:

$w_{j}$ : the weight of a criteria.

$\sum w_{j}$ : the total weight of all criteria

4) Developing single attribute utilities that reflect how well each alternative is seen from each criteria. This stage is to provide a value on all criteria for each alternative. In this field an expert estimates alternative values on a scale of $0-100$. Where 0 is the minimum value and 100 is the maximum value.

5) Calculating the valuation / utility of each alternative with equation (2):

Information:

$$
u_{i}\left(a_{i}\right)=100 \frac{\left(C_{\max }-C_{o u t i}\right)}{\left(C_{\max }-C_{\min }\right)} \%
$$

$u_{i}\left(a_{i}\right)$ : utility value of the 1 st criteria for the i-criteria

$C_{\max }$ : maximum criteria value

$C_{\min }:$ minimum criteria value 
$C_{\text {out } i}:$ the value of the i-criteria

6) Calculating the value of the Final Result with Equation (3):

$$
u\left(a_{i}\right)=\sum_{J=1}^{m} w_{j} u_{i}\left(a_{i}\right)
$$

Information:

$u\left(a_{i}\right)$ : utility;

$w_{j}$ : normalization of weights

7) Decided. If a single alternative is to be selected, then select the alternative with the greatest utility value.

\section{FMCDM Method}

The following is the workflow for the FMCDM method [6,12], consisting of 3 steps:

Representation of the Problem:

1) Determining the purpose of the decision, represented by natural language or numerical values according to the characteristics of the problem.

2) Determine alternative decisions. If there are $n$ alternatives, then write $A=\{A i \mid i=1,2, \ldots, n\}$.

3) Determining criteria. If there are k criteria, then it can be written $C=\{\mathrm{Ct} \mid \mathrm{t}=1,2, \ldots, \mathrm{k}\}$.

4) Forming a hierarchical decision structure.

\section{Evaluation of Fuzzy Sets:}

1) Selecting a set of ratings for the criteria weights, and the degree to which each alternative matches the criteria. The set of ratings consists of 3 elements, namely: a) linguistic variable (x) which represents the weight of the criteria, and the degree of compatibility of each alternative with the criteria; b) $\mathrm{T}(\mathrm{x})$ which represents the rating of the linguistic variable; c) The membership function associated with each element of $\mathrm{T}$ (x). Next, determine the membership function for each rating using the triangle function.

2) Evaluating the weights on each criteria and the degree of suitability of each alternative against the criteria.

3) Aggregating the criteria weights, and the degree of suitability of each alternative and its criteria with the mean method. The use of the mean operator is formulated in Equation (4) as follows:

$$
F_{i}=\left(\frac{1}{k}\right)\left[\begin{array}{l}
\left(S_{i 1} \otimes W_{1}\right) \oplus\left(S_{i 2} \otimes W_{2}\right) \oplus \ldots \oplus \\
\left(S_{i k} \otimes W_{k}\right)
\end{array}\right]
$$

By substituting $S_{i t}$ and $W_{t}$ with the triangular fuzzy number, $S_{i t}=\left(o_{i t}, p_{i t}, q_{i t}\right)$; and $W_{t}=\left(a_{t}, b_{t}, c_{t}\right)$; then $F_{t}$ be approached as Equation (5):

$$
F_{i} \cong\left(Y_{i}, Q_{i}, Z_{i}\right)
$$

With $\left(Y_{i}, Q_{i}, Z_{i}\right)$ as in Equations (6), (7), and (8):

$$
\begin{aligned}
Y_{i} & =\left(\frac{1}{k}\right) \sum_{t=1}^{k}\left(o_{i t}, a_{i}\right) \\
Q_{i} & =\left(\frac{1}{k}\right) \sum_{t=1}^{k}\left(p_{i t}, b_{i}\right) \\
Z_{i} & =\left(\frac{1}{k}\right) \sum_{t=1}^{k}\left(q_{i t}, c_{i}\right)
\end{aligned}
$$

Where, $\mathrm{i}=1,2,3, \ldots, \mathrm{n}$.

Optimal Alternative Selection:

1) Prioritizing alternative decisions based on the results of the aggregation for the ranking process alternative decisions using the total integral value method. If $F$ is a triangular fuzzy number, $F=(a, b, c)$, then the total integral value can be formulated as Equation (9) as follows: 


$$
I_{T}^{\alpha}(F)=\frac{1}{2}(\alpha c+b+(1-\alpha) a)
$$

The value $\alpha$ is the optimization index which represents the degree of optimism for the decision maker $(0 \leq \alpha \leq 1)$. If the value of $\alpha$ is getting bigger, it indicates that the degree of optimism is getting bigger.

2) Choosing the decision alternative with the highest priority as the optimal alternative.

C. Sensitivity

The calculation of the sensitivity value is done to measure the accuracy of a value. The search for sensitivity values is carried out in three ways, namely [20]:

1. Done by subtracting the results of the first alternative recommendation from the result of the second recommendation alternative, in general formulated in equation (10):

Information:

Total Sensitivity $=(\mathrm{Xa}-\mathrm{Xb})$

$\mathrm{Xa}=$ the value of the first alternative

$\mathrm{Xb}=$ second alternative value

2. Determination of sensitivity is done by dividing the results of the first recommendation alternative by the total number of alternatives. in general formulated in equation (11):

$$
\text { Total Sensitivity }=\mathrm{Xi} / \Sigma \mathrm{X}
$$

Information:

$\mathrm{Xi}=$ value of alternative $-\mathrm{i}$

$\sum \mathrm{X}=$ alternative value

3. Determination of sensitivity is done by summing the results of the first recommendation alternative with the results of the second recommendation alternative, then dividing it into two. In general formulated in equation (12):

$$
\text { Total Sensitivity }=1 / 2(\mathrm{Xa}+\mathrm{Xb})
$$

Information:

$\mathrm{Xa}=$ the value of the first alternative

$\mathrm{Xb}=$ second alternative value

\section{Results and Discussion}

\section{A. Implementation Phase}

The implementation phase starts from identifying the input data, then processing it with the FMCDM method, and ending with displaying the output of the implementation results.

Input requirements consist of:

1) Purpose of Decision: Selection of Customer Smartphone A.

2) Alternative decisions are as follows, the alternatives are dynamic:

a. Smartphone 1-A1 : Oppo Mirror 5

b. Smartphone 2-A2 : Oppo Joy Plus

c. Smartphone 3 - A3 : Asus Zenfone 2 Laser ZE500KG (16 GB)

3) Criteria for Decision Making as follows, the criteria are dynamic:
a. $\mathrm{C} 1$ : Price
b. $\mathrm{C} 2$ : Screen Size
c. C3 : Battery Capacity
d. C4: Operating System
e. C5 : RAM
f. C6 : Camera
g. C7 : Brand 
4) Hierarchical Structure of the Problem. Fig 1. Shows Hierarchical Structure of DSS Smartphone Selection.

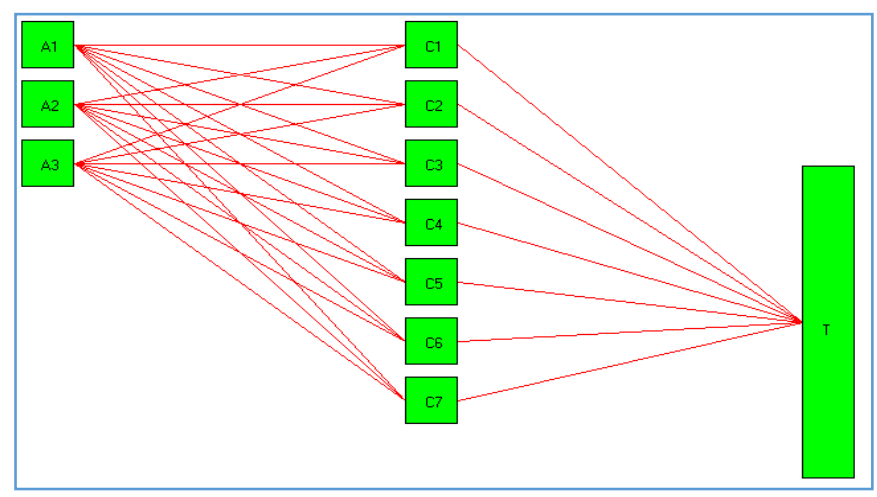

Fig 1. Hierarchical Structure of the DSS Smartphone Selection

The process requirement for this application is the SMART method and the FMCDM method. While the output requirements: a) Results of optimal alternative selection using the SMART and FMCDM methods in the form of ranking results, b) Comparative analysis results: similarities and differences between the SMART and FMCDM methods, c) The results of the sensitivity analysis of the two methods.

\section{B. Analysis of Results}

\section{SMART Method}

1) Determine the criteria, sub criteria, the value of each criteria, and the weight of the criteria. Table 1. presents 7 criterias, subcriteria, value, and weight of criteria on DSS Smartphone Selection.

Table 1. Value and Weight of Criteria and Sub Criteria

\begin{tabular}{|c|c|c|c|}
\hline No & Kriteria & \multirow{2}{*}{ Nilai } & \multirow{2}{*}{ Bobot $(\mathbf{w j})$} \\
\hline 1. & Harga & & \\
\hline & $8700000-10699000$ & 100 & \multirow{5}{*}{$30 \%$} \\
\hline & $6700000-8699000$ & 80 & \\
\hline & $4700000-6699000$ & 75 & \\
\hline & $2700000-4699000$ & 50 & \\
\hline & $700000-2699000$ & 40 & \\
\hline \multirow[t]{5}{*}{2.} & Ukuran Layar & & \\
\hline & $8^{\prime \prime}-9.9^{\prime \prime}$ & 75 & \multirow{4}{*}{$15 \%$} \\
\hline & $6 "-7.9 "$ & 60 & \\
\hline & $4^{\prime \prime}-5.9^{\prime \prime}$ & 50 & \\
\hline & $2^{\prime \prime}-3.9^{\prime \prime}$ & 40 & \\
\hline No & Kriteria & Nilai & Bobot (wi) \\
\hline \multirow[t]{4}{*}{3.} & Kapasistas Baterai & & \\
\hline & $3900 \mathrm{mAh}-5199 \mathrm{mAh}$ & 60 & \multirow{3}{*}{$5 \%$} \\
\hline & $2600 \mathrm{mAh}-3899 \mathrm{mAh}$ & 25 & \\
\hline & $1300 \mathrm{mAh}-2599 \mathrm{mAh}$ & 10 & \\
\hline \multirow[t]{5}{*}{4.} & Sistem Operasi & & \\
\hline & Lollipop & 100 & \multirow{4}{*}{$20 \%$} \\
\hline & KitKat & 80 & \\
\hline & Jelly Bean & 75 & \\
\hline & Marshmallow & 60 & \\
\hline \multirow[t]{7}{*}{5.} & RAM & & \multirow{7}{*}{$5 \%$} \\
\hline & $4 \mathrm{~GB}$ & 75 & \\
\hline & $3 \mathrm{~GB}$ & 60 & \\
\hline & $2 \mathrm{~GB}$ & 50 & \\
\hline & $1.5 \mathrm{~GB}$ & 40 & \\
\hline & $1 \mathrm{~GB}$ & 25 & \\
\hline & $<1 \mathrm{~GB}$ & 10 & \\
\hline \multirow[t]{5}{*}{6.} & Kamera & & \\
\hline & $20 m p-25 m p$ & 100 & \multirow{4}{*}{$15 \%$} \\
\hline & $14 m p-19 m p$ & 75 & \\
\hline & $8 m p-13 m p$ & 60 & \\
\hline & $2 m p-7 m p$ & 40 & \\
\hline \multirow[t]{7}{*}{7.} & Merk & & \\
\hline & Samsung & 100 & \multirow{6}{*}{$10 \%$} \\
\hline & Oppo & 80 & \\
\hline & Asus & 75 & \\
\hline & Lenovo & 60 & \\
\hline & Xiaomi & 50 & \\
\hline & Evercross & 25 & \\
\hline
\end{tabular}


2) Normalization of the Criteria weights. Table 2. presents weight and normalization weight of criteria.

Table 2. Normalized Criteria Weights

\begin{tabular}{|c|c|c|c|}
\hline No & Criteria & Weight (wi) & Normalization \\
\hline 1. & Price & $30 \%$ & 0.3 \\
\hline 2. & Screen Size & $15 \%$ & 0.15 \\
\hline 3. & Battery Capacity & $5 \%$ & 0.05 \\
\hline 4. & Operating System & $20 \%$ & 0.2 \\
\hline 5. & RAM & $5 \%$ & 0.5 \\
\hline 6. & Camera & $15 \%$ & 0.15 \\
\hline 7. & Brand & $10 \%$ & 0.1 \\
\hline & $\Sigma$ wi & $100 \%$ & 1 \\
\hline
\end{tabular}

3) Assign the value of each criteria for each alternative based on table 1 and calculate the results of the assessment of each alternative using Equation (2). Table 3. presents calculation process reesult by using SMART method.

Table 3. Calculation Results Using the SMART Method

\begin{tabular}{|c|c|c|c|c|c|c|}
\hline No & Alternative & Criteria & $\begin{array}{c}\text { Utility Value } \\
\qquad u_{i}\left(a_{i}\right)\end{array}$ & $\begin{array}{c}\text { Normalization } \\
\mathbf{W}_{\mathbf{j}}\end{array}$ & $\begin{array}{l}\text { The Final Result } \\
u\left(a_{i}\right)=\sum_{J=1}^{m} w_{j} u_{i}\left(a_{i}\right)\end{array}$ & Recommendation \\
\hline \multirow{7}{*}{1} & \multirow{7}{*}{$\begin{array}{l}\text { A1 - Oppo } \\
\text { Mirror } 5\end{array}$} & Price & 75 & 0.30 & \multirow{7}{*}{$\begin{array}{c}=(75 \times 0.30)+(75 \times 0.15)+ \\
(60 \times 0.05)+(100 \times 0.20)+ \\
(75 \times 0.05)+(75 \times 0.15)+ \\
(25 \times 0.10) \\
=74.25\end{array}$} & \multirow{7}{*}{ Be Considered } \\
\hline & & Screen Size & 75 & 0.15 & & \\
\hline & & Battery Capacity & 60 & 0.05 & & \\
\hline & & Operating System & 100 & 0.20 & & \\
\hline & & RAM & 75 & 0.05 & & \\
\hline & & Camera & 75 & 0.15 & & \\
\hline & & Brand & 25 & 0.10 & & \\
\hline \multirow{7}{*}{2} & \multirow{7}{*}{$\begin{array}{c}\text { A } 2 \text { - Oppo } \\
\text { Joy Plus }\end{array}$} & Price & 100 & 0.30 & \multirow{7}{*}{$\begin{array}{c}=(100 \times 0.3)+(75 \times 0.15)+ \\
(60 \times 0.05)+(75 \times 0.20)+ \\
(50 \times 0.05)+(60 \times 0.15)+ \\
(80 \times 0.10)=78.75\end{array}$} & \multirow{7}{*}{ Be Considered } \\
\hline & & Screen Size & 75 & 0.15 & & \\
\hline & & Battery Capacity & 60 & 0.05 & & \\
\hline & & Operating System & 75 & 0.20 & & \\
\hline & & RAM & 50 & 0.05 & & \\
\hline & & Camera & 60 & 0.15 & & \\
\hline & & Brand & 80 & 0.10 & & \\
\hline \multirow{7}{*}{3} & \multirow{7}{*}{$\begin{array}{l}\text { A3 - Asus } \\
\text { Zenfone } 2 \\
\text { Laser } \\
\text { ZE500KG } \\
(16 \mathrm{~GB})\end{array}$} & Price & 80 & 0.30 & \multirow{7}{*}{$\begin{array}{c}=(80 \times 0.3)+(80 \times 0.15)+ \\
(100 \times 0.05)+(75 \times 0.20)+ \\
(80 \times 0.05)+(75 \times 0.15)+ \\
(100 \times 0.10)=81.25\end{array}$} & \multirow{7}{*}{ Recommanded } \\
\hline & & Screen Size & 80 & 0.15 & & \\
\hline & & Battery Capacity & 100 & 0.05 & & \\
\hline & & Operating System & 75 & 0.20 & & \\
\hline & & RAM & 80 & 0.05 & & \\
\hline & & Camera & 75 & 0.15 & & \\
\hline & & Brand & 100 & 0.10 & & \\
\hline
\end{tabular}

4) Determining Decision Value Standards. The rating limits start from 0 as the lowest range to 100 as the highest range, so in the end the eligibility of choosing a smartphone is measured with a value of $80-100$ for the recommended category to be purchased, 60-79.99 for the considered category, and 0-59.99 for the category not recommended for purchase [32]. Table 4 presents the decision results using the SMART method, it can be seen that the results of the assessment of the Asus Zenfone 2 Laser ZE500KG (16 GB) smartphone are higher than the Oppo Mirror 5 and Oppo Joy Plus, so it can be concluded that the Asus Zenfone 2 Laser ZE500KG (16 GB) is recommended as the smartphone of choice for customers to buy.

Table 4. Results of the SMART Method Decision

\begin{tabular}{|c|c|c|c|}
\hline No & Alternative & The Final Result & Recommendation \\
\hline 1 & A1 - Oppo Mirror 5 & 74.25 & Be Concidered \\
\hline 2 & A2 - Oppo Joy Plus & 78.75 & Be Concidered \\
\hline 3 & A3 - Asus Zenfone 2 Laser ZE500KG (16 GB) & 81.25 & Rekommended \\
\hline
\end{tabular}

\section{FMCDM Method}

1) Determining criteria and subcriteria. Table 5. Shows for each criteria, it has the same subcriteria.

Table 5. Criteria dan Sub Criteria

\begin{tabular}{|c|c|c|c|}
\hline No & Criteria & Sub Criteria & Value \\
\hline 1. & Price & \multirow{7}{*}{$\begin{array}{l}\text { Very Low } \\
\text { Low } \\
\text { Enough } \\
\text { High } \\
\text { Very High }\end{array}$} & \multirow{7}{*}{$\begin{array}{c}(0,0,0.25) \\
(0,0.25,0.5) \\
(0.25,0.5,0.75) \\
(0.5,0.75,1) \\
(0.75,1,1)\end{array}$} \\
\hline 2. & Screen Size & & \\
\hline 3. & Battery Capacity & & \\
\hline 4. & Operating System & & \\
\hline 5. & RAM & & \\
\hline 6. & Camera & & \\
\hline 7. & Brand & & \\
\hline
\end{tabular}


2) Determine the Importance Rating of Each Criteria. The value on the importance rating in Table 6 is assumed to be equalized by the weight normalization value in the SMART method as shown in Table 2.

Table 6. Rating of Interest for Each Criteria

\begin{tabular}{|c|c|c|c|c|}
\hline No & Criteria & $\begin{array}{c}\text { Weight On } \\
\text { SMART }\end{array}$ & $\begin{array}{c}\text { Sub Criteria } \\
\text { On FMCDM }\end{array}$ & Value \\
\hline 1. & Price & 0.3 & Very High & $(0.75,1,1)$ \\
\hline 2. & Screen Size & 0.15 & Enough & $(0.25,0.5,0.75)$ \\
\hline 3. & Battery Capacity & 0.05 & Very Low & $(0,0,0.25)$ \\
\hline 4. & Operating System & 0.2 & High & $(0.5,0.75,1)$ \\
\hline 5. & RAM & 0.05 & Very Low & $(0,0,0.25)$ \\
\hline 6. & Camera & 0.15 & Enough & $(0.25,0.5,0.75)$ \\
\hline 7. & Brand & 0.1 & Low & $(0,0.25,0.5)$ \\
\hline
\end{tabular}

3) Determine the Suitability Rating of Each Alternative Against Each Criteria. The Suitability Rating of Each Alternative Against Each Criteria in Table 7. is assumed to equalize the weight normalization value in the SMART method as shown in Table 3.

Table 7. Assumed Value of Each Criteria for Each Alternative

\begin{tabular}{|c|c|c|}
\hline No & Sub Criteria On FMCDM & Utility Value On SMART \\
\hline 1. & Very Less & $0-20$ \\
\hline 2. & Less & $21-40$ \\
\hline 3. & Enogh & $41-60$ \\
\hline 4. & Good & $61-80$ \\
\hline 5. & Very Good & $81-100$ \\
\hline
\end{tabular}

4) Calculating the Fuzzy Suitability Index Value of Each Alternative. Table 8 shows the Calculations Fuzzy Match Index for Each Alternative using equations (6), (7), and (8).

Table 8. Fuzzy Match Index for Each Alternative

\begin{tabular}{|c|c|c|c|c|c|c|c|}
\hline \multirow{2}{*}{ No } & \multirow{2}{*}{ Alternative } & \multirow{2}{*}{ Criteria } & \multirow{2}{*}{$\begin{array}{c}\text { Utility } \\
\text { Value on } \\
\text { SMART }\end{array}$} & \multirow{2}{*}{$\begin{array}{c}\text { Sub Criteria } \\
\text { Value on } \\
\text { FMCDM }\end{array}$} & \multicolumn{3}{|c|}{ Fuzzy Match Index } \\
\hline & & & & & $\mathbf{Y}$ & $\mathbf{Q}$ & $\mathbf{Z}$ \\
\hline \multirow{7}{*}{1} & \multirow{7}{*}{$\begin{array}{l}\text { A1 - Oppo } \\
\text { Mirror } 5\end{array}$} & Price & 75 & Good & \multirow{7}{*}{$\begin{array}{c}=((0.75 \times 0.5)+ \\
(0.25 \times 0.5)+ \\
(0 \times 0.25)+ \\
(0.5 \times 0.75)+ \\
(0 \times 0.5)+ \\
(0.25 \times 0.5)+ \\
(0 \times 0)) / 7 \\
=0.14285\end{array}$} & \multirow{7}{*}{$\begin{array}{c}=((1 \times 0.75)+ \\
(0.5 \times 0.75)+ \\
(0 \times 0.5)+ \\
(0.75 \times 1)+ \\
(0 \times 0.75)+ \\
(0.5 \times 0.75)+ \\
(0.25 \times 0.25)) / 7 \\
=0.33035\end{array}$} & \multirow{7}{*}{$\begin{array}{c}=((1 \times 1)+ \\
(0.75 \times 1)+ \\
(0.25 \times 0.75)+ \\
(1 \times 1)+ \\
(0.25 \times 1)+ \\
(0.75 \times 1)+ \\
(0.5 \times 0.5)) / 7 \\
=0.5982\end{array}$} \\
\hline & & Screen Size & 75 & Good & & & \\
\hline & & $\begin{array}{c}\text { Battery } \\
\text { Capacity }\end{array}$ & 60 & Enough & & & \\
\hline & & $\begin{array}{l}\text { Operating } \\
\text { System }\end{array}$ & 100 & Very Good & & & \\
\hline & & RAM & 75 & Good & & & \\
\hline & & Camera & 75 & Good & & & \\
\hline & & Brand & 25 & Less & & & \\
\hline \multirow{7}{*}{2} & \multirow{7}{*}{$\begin{array}{c}\text { A2 - Oppo } \\
\text { Joy Plus }\end{array}$} & Price & 100 & Very Good & \multirow{7}{*}{$\begin{array}{c}=((0.75 \times 0.75)+ \\
(0.25 \times 0.5)+ \\
(0 \times 0.25)+ \\
(0.5 \times 0.5)+ \\
(0 \times 0.25)+ \\
(0.25 \times 0.25)+ \\
(0 \times 0.5)) / 7= \\
0.14285\end{array}$} & \multirow{7}{*}{$\begin{array}{c}=((1 \times 1)+ \\
(0.5 \times 0.75)+ \\
(0 \times 0.5)+ \\
(0.75 \times 0.75)+ \\
(0 \times 0.5)+ \\
(0.5 \times 0.5)+ \\
(0.25 \times 0.75)) / 7 \\
=0.3392\end{array}$} & \multirow{7}{*}{$\begin{array}{c}=((1 \times 1)+ \\
(0.75 \times 1)+ \\
(0.25 \times 0.75)+ \\
(1 \times 1)+ \\
(0.25 \times 0.75)+ \\
(0.75 \times 0.75)+ \\
(0.5 \times 1)) / 7 \\
=0.5982\end{array}$} \\
\hline & & Screen Size & 75 & Good & & & \\
\hline & & $\begin{array}{c}\text { Battery } \\
\text { Capacity }\end{array}$ & 60 & Enough & & & \\
\hline & & $\begin{array}{l}\text { Operating } \\
\text { System }\end{array}$ & 75 & Good & & & \\
\hline & & RAM & 50 & Enough & & & \\
\hline & & Camera & 60 & Enough & & & \\
\hline & & Brand & 80 & Good & & & \\
\hline \multirow{7}{*}{3} & \multirow{7}{*}{$\begin{array}{c}\text { A3 - Asus } \\
\text { Zenfone } 2 \\
\text { Laser } \\
\text { ZE500KG } \\
(16 \mathrm{~GB})\end{array}$} & Price & 80 & Good & \multirow{7}{*}{$\begin{array}{c}=((0.75 \times 0.5)+ \\
(0.25 \times 0.5)+ \\
(0 \times 0.75)+ \\
(0.5 \times 0.5)+ \\
(0 \times 0.5)+ \\
(0.25 \times 0.5)+ \\
(0 \times 0.75)) / 7 \\
=0.125\end{array}$} & \multirow{7}{*}{$\begin{array}{c}=((1 \times 0.75)+ \\
(0.5 \times 0.75)+ \\
(0 \times 1)+ \\
(0.75 \times 0.75)+ \\
(0 \times 0.75)+ \\
(0.5 \times 0.75)+ \\
(0.25 \times 1)) / 7 \\
=0.33035\end{array}$} & \multirow{7}{*}{$\begin{array}{c}=((1 \times 1)+ \\
(0.75 \times 1)+ \\
(0.25 \times 1)+ \\
(1 \times 1)+ \\
(0.25 \times 1)+ \\
(0.75 \times 1)+ \\
(0.5 \times 1)) / 7 \\
=0.64285\end{array}$} \\
\hline & & Screen Size & 80 & Good & & & \\
\hline & & $\begin{array}{c}\text { Battery } \\
\text { Capacity }\end{array}$ & 100 & Very Good & & & \\
\hline & & $\begin{array}{l}\text { Operating } \\
\text { System }\end{array}$ & 75 & Good & & & \\
\hline & & RAM & 80 & Good & & & \\
\hline & & Camera & 75 & Good & & & \\
\hline & & Brand & 100 & Very Good & & & \\
\hline
\end{tabular}

5) Optimal Alternative Selection. This is done by calculating the total value of the integral based on equation (9), as shown in Table 9. The Total Integral value can be calculated based on the degree of optimism (0 to 1). Based on Table 9., it can be seen that the smartphone recommended for purchase by customers is the Asus Zenfone 2 Laser ZE500KG (16 GB) smartphone with the highest value for the parameter $\alpha=0.5$ to 1.0. 
Table 9. Selection of Alternative Solutions

\begin{tabular}{|c|c|c|c|c|c|c|}
\hline No & Alternative & $\begin{array}{c}\text { Total } \\
\text { Integral } \\
\text { Value } \\
(\boldsymbol{\alpha}=\mathbf{0 . 1})\end{array}$ & Recommendation & $\begin{array}{c}\text { Total } \\
\text { Integral } \\
\text { Value } \\
(\boldsymbol{\alpha}=\mathbf{0 . 5})\end{array}$ & $\begin{array}{c}\text { Total } \\
\text { Integral } \\
\text { Value } \\
(\boldsymbol{\alpha}=\mathbf{1 . 0})\end{array}$ & Recommendation \\
\hline 1 & A1 - Oppo Mirror 5 & 0.2593 & Be Considered 1 & 0.3504 & 0.4642 & Be Considered 2 \\
\hline 2 & A2 - Oppo Joy Plus & 0.2638 & Rekommended & 0.3549 & 0.46875 & Be Considered 1 \\
\hline 3 & $\begin{array}{c}\text { A3 - Asus Zenfone 2 Laser } \\
\text { ZE500KG (16 GB) }\end{array}$ & 0.2535 & Be Considered 2 & 0.35714 & 0.4866 & Rekommended \\
\hline
\end{tabular}

\section{Discussion of Results Analysis}

The final result of the calculation shows that both the SMART method and the FMCDM method give the same recommendation, namely the Asus Zenfone 2 Laser ZE500KG (16 GB) smartphone with the highest final result value, so it is advisable to customer A to buy a smartphone of this brand. Table 10 shows a comparison of the final result values.

Table 10. Comparison of the Final Results of the SMART and FMCDM Methods

\begin{tabular}{|c|c|c|}
\hline Alternative & $\begin{array}{c}\text { The Final Result } \\
\text { SMART Method }(\boldsymbol{\%})\end{array}$ & $\begin{array}{c}\text { The Final Result FMCDM } \\
\text { Method }(\boldsymbol{\alpha}=\mathbf{1 . 0})\end{array}$ \\
\hline A1 - Oppo Mirror 5 & 0.7425 & 0.4642 \\
\hline A2 - Oppo Joy Plus & 0.7875 & 0.4687 \\
\hline $\begin{array}{c}\text { A3 - Asus Zenfone 2 Laser } \\
\text { ZE500KG (16 GB) }\end{array}$ & 0.8125 & 0.4866 \\
\hline
\end{tabular}

Furthermore, Table 11 shows a comparison of the defferences calculation process of the two methods.

Table 11. Comparison of the SMART and FMCDM Process Methods

\begin{tabular}{|c|c|c|c|c|c|}
\hline Method & $\begin{array}{c}\text { Sub } \\
\text { Criteria }\end{array}$ & Normalisasi Bobot & Final Formula & $\begin{array}{c}\text { Range } \\
\text { Value }\end{array}$ & Decision Standard \\
\hline SMART & $\begin{array}{c}\text { Number } \\
\text { Variable }\end{array}$ & $\begin{array}{c}\text { Variable Number: } \\
\text { Weight / Total Total } \\
\text { Weight\% }\end{array}$ & $\begin{array}{c}\text { Final Result }= \\
u\left(a_{i}\right)=\sum_{J=1}^{m} w_{j} u_{i}\left(a_{i}\right)\end{array}$ & $0-100$ & $\begin{array}{c}0-59.99: \text { Not Recommended } \\
60-79.99: \text { Be considered } \\
80-100: \text { Recommended }\end{array}$ \\
\hline FMCDM & $\begin{array}{c}\text { Linguistic } \\
\text { Variable } \\
\text { and } \\
\text { Number } \\
\text { Variable }\end{array}$ & $\begin{array}{c}\text { Lunguistic Variables } \\
\text { and Numbers: } \\
\text { Importance Rating } \\
\text { and Fit Rating }\end{array}$ & $\begin{array}{c}\text { Total Integral Value }= \\
I_{T}^{\alpha}(\boldsymbol{F})\end{array}$ & $0-1$ & $\begin{array}{c}\text { Highest Total Integral Value as a } \\
\text { recommen-dation for a decision } \\
\text { (Do not use value range } \\
\text { classification) }\end{array}$ \\
\hline
\end{tabular}

In determining recommendations, both the final results of the SMART method and the FMCDM method are in the form of ranking. Where the results are sorted based on the total value of the largest to the smallest. Furthermore, measuring the accuracy of the calculation results using the SMART and FMCDM methods using sensitivity analysis with the results. From Table 12, it is known that the method that can be applied to the DSS for selecting smartphones on Maju Jaya Cell Store is the FMCDM method because it has the smallest average sensitivity value. The smaller the sensitivity value, the better.

Table 12. Value of Sensitivity Analysis

\begin{tabular}{|c|c|c|}
\hline Sensitivity & SMART Method & FMCDM Method \\
\hline Way 1 & 0.025 & 0.0179 \\
\hline Way 2 & 0.3468 & 0.3430 \\
\hline Way 3 & 0.8 & 0.4776 \\
\hline Average & 0.3906 & 0.2795 \\
\hline
\end{tabular}

Previous research [11] on the comparison of Fuzzy SAW and SMART methods in determining permanent employees showed the same decision results, namely that there were 5 recommended employees and 7 employees who were not recommended. Meanwhile, to compare the decision results of the two methods, by calculating the difference between the standard value of the decision and the value obtained by each alternative. From the results of the calculation of this difference, it is found that the Fuzzy SAW method is closer to the standard determined decision value than the SMART method. So it can be concluded that the use of the Fuzzy SAW method in this case is better than the SMART method.

Meanwhile, a similar comparison of previous studies on smartphone selection $[23,24]$ shows the results of the decision to purchase the same smartphone, namely the smartphone of the same brand and type. However, both studies have not shown the best method decision results between the TOPISIS and MOORA methods [23] and between the 
SMARTER and TOPSIS methods [24]. The results of the comparison of these methods only conclude that the combination of the two methods is good. This study has the advantages of previous similar studies, namely that it can be concluded that the better method to be applied is the Fuzzy MCDM method than the SMART method based on the calculation of the sensitivity value.

\section{Conclusion}

The basic principle of the calculation process in both the SMART method and the FMCDM method is influenced by the value of each criteria and sub-criteria for each alternative value and does not depend on variables of interest or weight normalization. Both methods have a similarity, namely in determining the final result for a decision based on the ranking from the highest, so the smartphone recommended to buy is the one that has the highest final result value of the two methods, namely the same type of smartphone Asus Zenfone 2 Laser ZE500KG (16 GB). Whereas the difference between the SMART method and the FMCDM method is seen in the calculation process step, where the FMCDM method uses the total integral value based on the degree of optimism $(\alpha)$ while the SMART method does not. Based on the results of the sensitivity analysis, the FMCDM method is better than the SMART method with an average sensitivity value of 0.2795 which is smaller than the SMART method, namely 0.3906 . The smaller the sensitivity value, the better.

Likewise with the results of previous studies, a comparison of the SMART and Fuzzy SAW methods on the DSS for determining permanent employees [11], that the Fuzzy SAW method is better because the results are closer to the predetermined decision value standard compared to the SMART method. From the two comparisons above, it can be concluded that the application of fuzzy logic method both Fuzzy MCDM and Fuzzy SAW methods in an DSS can be applied better than the SMART method.

From the results of the comparative analysis of the calculation process of the two methods, when viewed from the steps to solve, the SMART method is simpler than the FMCDM method, so the use of the SMART method can be applied to simple problem solving cases that do not use a lot of data, while the FMCDM method can be applied to problems more complex ones that require a lot of data and criteria.

With this research, it can provide a new reference for further research, especially research on Decision Support Systems. Based on the results of the conclusions, this research can be tried to be further developed with other methods including using Artificial Neural Networks for later comparative analysis can be carried out with the methods that have been applied.

\section{References}

[1] Efraim Turban, Jay E Aronson, Ting Peng Liang, “Decision Support System and Intelligent System Sevent Edition”, Prentice Hall Of Inida, New Delhi 2007.

[2] Taylor, M., Reilly, D., \& Wren, C. (2020). Internet of things support for marketing activities. Journal of Strategic Marketing, 28(2), 149-160.

[3] Ashton, K. (2009). That 'internet of things' thing. RFID journal, 22(7), 97-114.

[4] Villa-Henriksen, A., Edwards, G. T., Pesonen, L. A., Green, O., \& Sørensen, C. A. G. (2020). Internet of Things in arable farming: Implementation, applications, challenges and potential. Biosystems Engineering, 191, 60-84..

[5] Javier Ferrandez-Pastor, F., Manuel Garcia-Chamizo, J., Nieto-Hidalgo, M., Mora-Pascual, J., \& Mora-Martinez, J. (2016). Developing ubiquitous sensor network platform using internet of things: application in precision agriculture. Sensors, 16(7).

[6] N. Kahar dan Riki, "Application of the Fuzzy Multi Criteria Decision Making Method in the Smartphone Selection Decision Support System (In Indonesia Penerapan Metode Fuzzy Multi Criteria Decision Making Pada Sistem Pendukung Keputusan Pemilihan Smartphone)", Fortech (Journal Of Information Technology) Volume 1 Nomor 1 Juli 2017, Available: http://ojs.stmiknh.ac.id/ index.php/fortech/article/view/68.

[7] Jo, Y. S., Bhang, S. Y., Choi, J. S., Lee, H. K., Lee, S. Y., \& Kweon, Y. S. (2020). Internet, gaming, and smartphone usage patterns of children and adolescents in Korea: A c-CURE clinical cohort study. Journal of Behavioral Addictions.

[8] Iskandar, "Indonesian Smartphone Shopping Interest Up 21 Percent (In Indonesia Minat Belanja Smartphone Orang Indonesia Naik 21 Persen)", Liputan 6, Available: https://www.liputan6.com/tekno/read/3520036/minat-belanja-smartphone-orangindonesia-naik-21-persen.

[9] Riki, "Smartphone Selection Decision Support System Using Simple Multy Attribute Rating Weighting Method (In Indonesia Sistem Pendukung Keputusan Pemilihan Smartphone Dengan Metode Pembobotan Simple Multy Attribute Rating)", Skripsi Tahun 2016.

[10] Oktavianti, E., Komala, N., \& Nugrahani, F. (2019, April). Simple multi attribute rating technique (SMART) method on employee promotions. In Journal of Physics: Conference Series (Vol. 1193, No. 1, p. 012028). IOP Publishing.

[11] H. Priatna, Dedih, dan J. Mulyana, "Comparison of SMART and Simple Additive Weighting (SAW) Methods in Determining Web-Based Permanent Employees (In Indonesia Perbandingan Metode SMART Dan Simple Additive Weighting (SAW) Dalam Menentukan Karyawan Tetap Berbasis Web)", UNSIKA Syntax Jurnal Informatika Vol. 5 No. 1, 2016, 53-85, Juli 2016 [online]. Available: https://journal.unsika.ac.id/index.php/syntax/article/download/701/603. [Accessed: 27-Agustus-2020].

[12] S. Kusumadewi, "Fuzzy Multi Attribute Decision Making", Yogyakarta: Graha Ilmu, 2006.

[13] Ortiz-Barrios, M., Cabarcas-Reyes, J., Ishizaka, A., Barbati, M., Jaramillo-Rueda, N., \& de Jesús Carrascal-Zambrano, G. (2020). A hybrid fuzzy multi-criteria decision making model for selecting a sustainable supplier of forklift filters: a case study from the mining industry. Annals of Operations Research, 1-39 
[14] Li, J., Li, Z., Liu, S. F., \& Cheng, M. (2020). Applying a fuzzy, multi-criteria decision-making method to the performance evaluation scores of industrial design courses. Interactive Learning Environments, 28(2), 191-205.

[15] D. R. Habibie, "Decision Support System for Selection of Ideal Teacher Position Using Fuzzy Multi Criteria Decision Making Method (Case Study at SMP Mondial Batam) (In Indonesia Sistem Pendukung Keputusan Penyeleksian Posisi Guru Ideal Menggunakan Metode Fuzzy Multi Criteria Decision Making (Studi Kasus Di SMP Mondial Batam))," JURSIMA Jurnal Sistem Informasi dan Manajemen, Volume 5 No. 1 Mei 2017 [online]. Available: http://ejournal.stmikgici.ac.id/index.php/jursima/article/ view/3/9.

[16] Edjossan-Sossou, A. M., Galvez, D., Deck, O., Al Heib, M., Verdel, T., Dupont, L., ... \& Morel, L. (2020). Sustainable risk management strategy selection using a fuzzy multi-criteria decision approach. International Journal of Disaster Risk Reduction, 45, 101474.

[17] Basrie, B., \& Yulsilviana, E. Decision Support System for Selecting Students to Follow Biological Science Olympiad Using Simple Multi Attribute Rating Technique (SMART) Method. Tepian, 1(2), 74-78.

[18] Setiawan, W., Pranoto, N., \& Huda, K. (2020). Employee Performance Evaluation Decision Support System with the SMART (Simple Multi-Attribute Rating Technique) Method. Jurnal RESTI (Rekayasa Sistem Dan Teknologi Informasi), 4(1), 50-55.

[19] Rahadjeng, I. R., \& Windarto, A. P. (2019). Implementation of Simple Multi Attribute Rating Technique Method using Decision Support System Concept (Case Recommendation of Salon Place in Pematangsiantar City). IJISTECH (International Journal of Information System \& Technology), 3(1), 25-30.

[20] R. D. Kusmiyanti, Suliatun, dan Mustakim, "Sensitivity Analysis of the SMART-AHP Model with SMARTER-ROC as Multi Criteria Decision Making for the National Seminar on Information Technology (In Indonesia Analisis Sensitivitas Model SMART-AHP dengan SMARTER-ROC sebagai Pengambilan Keputusan Multi Kriteria Seminar Nasional Teknologi Informasi)", SNTIKI 9 UIN Sultan Syarif Kasim Riau Pekanbaru, Mei 2017 [online]. Available: http://ejournal.uinsuska.ac.id/index.php/SNTIKI/ article/view/3266/2155.

[21] Pehlivan, N. Y., Şahin, A., Zavadskas, E. K., \& Turskis, Z. (2018). A comparative study of integrated FMCDM methods for evaluation of organizational strategy development. Journal of Business Economics and Management, 19(2), 360-381.

[22] Pinem, A. P. R., Handayani, T., \& Huizen, L. M. (2020). Comparison of the ELECTRE, SMART and ARAS Methods in Determining Priority for Post-Natural Disaster RENAKSI Priorities. Jurnal RESTI (Rekayasa Sistem Dan Teknologi Informasi), 4(1), 109-116.

[23] Kumar, S., Kumar, T. A., \& Agrawal, S. (2020). Research Methodology: Prioritization of New Smartphones Using TOPSIS and MOORA. T Ashwin and Agrawal, Saurabh, Research Methodology: Prioritization of New Smartphones Using TOPSIS and MOORA (April 15, 2020).

[24] Hidayatullah, A. N., Yunita, Y., \& Yusliani, N. (2020). Sistem Pendukung Keputusan Pemilihan Smartphone Android Menggunakan Metode Smarter Dan Topsis (Doctoral dissertation, Sriwijaya University).

[25] Cahyadsn, "Simple Multi Attribute Rating Technique (SMART) (In Indonesia Simple Multi Attribute Rating Technique (SMART))", Available: https://cahyadsn.phpindonesia.id/extra/smart.php.

[26] B. Suharjo, Suparno, R. Njib, "The Fuzzy Mcdm Approach for the Selection of Air-Attack Defending Weapons for the Kri Makassar Class LPD Ship (In Indonesia Pendekatan Fuzzy Mcdm Untuk Pemilihan Senjata Penangkis Serangan Udara Untuk Kapal LPD Kelas Kri Makassar)”, Available: http://sttal.ac.id/wp-content/uploads/2016/07/Tahun-2015-Vol.-3-1.pdf.

[27] Nurmuhlis, "Fuzzy Logic (In Indonesia Logika Fuzzy)", Available: https://nurmuhlis.wordpress.com/2011/03 /01/logika-fuzzy/.

[28] Ali, S., Ullah, N., Abrar, M. F., Yang, Z., \& Huang, J. (2020). Fuzzy Multicriteria Decision-Making Approach for Measuring the Possibility of Cloud Adoption for Software Testing. Scientific Programming, 2020.

[29] T. H. Chang and T. C. Wang, "Using the fuzzy multi-criteria decision making approach for measuring the possibility of successful knowledge management," Information Sciences, vol. 179, no. 13, pp. 355-370, 2009.

[30] A. Sangaiah and A. Thangavelu, "An exploration of FMCDM approach for evaluating the outcome/success of GSD projects," Central European Journal of Engineering, vol. 3, pp. 419-435, 2013.

[31] M.-S. Kuo and G.-S. Liang, "A soft computing method of performance evaluation with MCDM based on interval-valued fuzzy numbers," Applied Soft Computing, vol. 12, no. 1, pp. 476-485, 2012.

[32] Y.-J. Wang, "Applying FMCDM to evaluate financial performance of domestic airlines in Taiwan," Expert Systems with Applications, vol. 34, no. 3, pp. 1837-1845, 2008.

[33] K. Nizar, "Decision Support System in Choosing a Bank as a Place of Savings in Malang City Using the Simple Multi Attribute Rating Technique (SMART) Method (In Indonesia Sistem Pendukung Keputusan Dalam Pemilihan Bank Sebagai Tempat Menabung Di Kota Malang Dengan Menggunakan Metode Simple Multi Attribute Rating Technique (SMART))", Available: http://nizarnasti.blogspot.com/.

\section{Authors' Profiles}

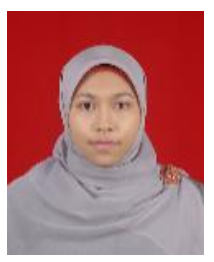

Novhirtamely Kahar, She graduated from SMU Negeri 1 Jambi, completed her undergraduate education majoring in infromatic engineering at UII Yogyakarta in 2003, and graduated postgraduate in information technology at UPI YPTK Padang in 2015. Began working as a lecturer in the informatics engineering study program STMIK Nurdin Hamzah in 2006. Research field in accordance with the areas of competence, namely Intelligent Systems: Decision support systems, data mining, fuzzy logic and artificial neural networks. 


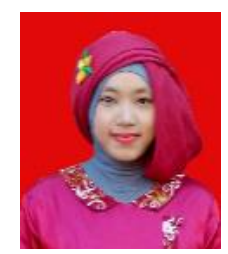

Riki, She graduated from SMK Negeri 1 Batang Hari majoring in Multimedia and completed his undergraduate education majoring in informatics engineering at STMIK Nurdin Hamzah in 2016. Job Training uses the Delphi programming language, discusses information systems in a car repair shop. The scription research discusses the Decision Support System with a simple multi-attribute rating technique method, using a web programming language.

How to cite this paper: Novhirtamely Kahar, Riki, " Comparative Study of SMART and FMCDM Methods in Smartphone Selection Decision Support System", International Journal of Image, Graphics and Signal Processing(IJIGSP), Vol.13, No.4, pp. 1-13, 2021.DOI: 10.5815/ijigsp.2021.04.01 